\title{
Quality Assessment of Surface and Drinking Water of Nakla Paurosova, Sherpur, Bangladesh
}

\author{
Sourav Sarker1, Shahin Mahmud1, Razia Sultana², Ritu Biswas ${ }^{3}$, Partha Protim Sarkar4, \\ Md. Abul Munayem1, Nur-E-Alam1', Md. Rayhan Ali', Muhammad Wasim1', Md. Firoz Ali1, \\ Md. Omar Faruque ${ }^{1}$, Fatematuz Zuhura Evamoni2 ${ }^{*}$ \\ ${ }^{1}$ Department of Biotechnology and Genetic Engineering, Mawlana Bhashani Science and Technology University, \\ Tangail, Bangladesh \\ ${ }^{2}$ Department of Biotechnology and Genetic Engineering, Noakhali Science and Technology University, Noakhali, Bangladesh \\ ${ }^{3}$ Department of Biotechnology and Genetic Engineering, Bangabandhu Sheikh Mujibur Rahman Science and Technology \\ University, Gopalganj, Bangladesh \\ ${ }^{4}$ Department of Biotechnology, Bangladesh Agricultural University, Mymensingh, Bangladesh \\ Email: *eva.nstu@yahoo.com
}

How to cite this paper: Sarker, S., Mahmud, S., Sultana, R., Biswas, R., Sarkar, P.P., Munayem, Md.A., Nur-E-Alam, Ali, Md.R., Wasim, M., Ali, Md.F., Faruque, Md.O. and Evamoni, F.Z. (2019) Quality Assessment of Surface and Drinking Water of Nakla Paurosova, Sherpur, Bangladesh. Advances in Microbiology, 9, 703-727. https://doi.org/10.4236/aim.2019.98043

Received: May 30, 2019

Accepted: August 6, 2019

Published: August 9, 2019

Copyright $\odot 2019$ by author(s) and Scientific Research Publishing Inc. This work is licensed under the Creative Commons Attribution International License (CC BY 4.0).

http://creativecommons.org/licenses/by/4.0/

\begin{abstract}
Water is one of the most vital elements of ecosystem and human being, but unfortunately nowadays, the pollution of surface and drinking water is an alarming problem. The present work deals with the assessment of physicochemical and bacteriological profile of several pond, jar and tube-well water samples to ensure its suitability for using and drinking. Total 30 samples were randomly selected and collected from Nakla Paurosova of Sherpur district by following the standard procedure. Bacteriological analysis was carried out by following the standard bacteriological methods. Most of the surface water sampling points were polluted by dumping of waste, cattle wash and were not suitable for drinking or other domestic purposes. Among three heavy metals, only Iron was detected in six tube-well water samples, one was also positive to arsenic, rest of the water bodies were negative to all of these metals. In case of most of the water bodies, different physicochemical properties were below standard limit. In pond water, the Total Viable Count (TVC) ranged from 2.7 $\times 10^{7} \mathrm{cfu} / 100 \mathrm{ml}$ to $4.4 \times 10^{15} \mathrm{cfu} / 100 \mathrm{ml}$ and Total Coliform Count (TCC) were $3.4 \times 10^{5} \mathrm{cfu} / 100 \mathrm{ml}$ to $4.8 \times 10^{13} \mathrm{cfu} / 100 \mathrm{ml}$, where the mean concentration of Heterotrophic Plate Count (HPC) was $2.4 \times 10^{5} \mathrm{cfu} / 100 \mathrm{ml}$ and $1.8 \times$ $10^{5} \mathrm{cfu} / 100 \mathrm{ml}$ in jar and tube-well water respectively. On the other hand, the Total Coliform Count of supply water was $33 \mathrm{cfu} / 100 \mathrm{ml}$ and tube-well water was $14 \mathrm{cfu} / 100 \mathrm{ml}$. Fecal coliform was detected in all of the pond water samples, four jar and three tube-well water too. E. coli was present in all pond
\end{abstract}


water samples, and also detected in $80 \%$ supply and $50 \%$ tube-well water also. Shigella spp. was found in two pond water and in one supply water, where tube-well water was free from it. Salmonella spp. was also detected in $30 \%$ of pond and $20 \%$ of supply water, whereas absent in tube-well water. $50 \%$ of pond, $40 \%$ of supply and $30 \%$ of tube-well water were contaminated with $\mathrm{Vi}$ brio spp. The total counts of these pathogenic bacteria exceeded the acceptable limit both surface and drinking water and also showed resistance against a broad range of commercially available antibiotics. Survey-based result revealed that, peoples of the study area who were using or drinking these water, were suffering from various water borne diseases. These kinds of water sources pose a major threat to public health. So, public awareness, proper treatment and precise management are needed prior to use and drink of these water.

\section{Keywords}

Physiochemical Parameters, Bacterial Load, Antibiogram, Public Health, Nakla Paurosova

\section{Introduction}

Safe drinking water access for urban and rural populations in developing countries remains a challenge for sustainable development [1]. Water is essential to the existence of all living organisms. The environment, economic growth and developments of Bangladesh are all highly influenced by surface water because of its regional and seasonal availability [2]. This valued resource is increasingly being threatened as human populations grow. Demand also increasing day by day for more water of high quality for domestic purposes and economic activities [3]. Water quality can be defined by the chemical, physical and biological contents of water. The water quality of the surface water bodies of our country is decreasing by both conventional pollutants (heavy metals, pesticides), different organic or inorganic compounds and micro pollutants [4] [5]. Poor water quality may be caused by low water flow, municipal effluents and industrial discharges [6]. Degradation of water quality, depletion of water resources and loss of aquatic biodiversity are prominent features of the environmental landscape, which is requiring urgent attention at global and national scales [7]. Important physical and chemical parameters influencing the aquatic environment are temperature, rainfall, $\mathrm{pH}$, salinity, dissolved oxygen and carbon dioxide. These parameters are the limiting factors for the survival of aquatic organisms. The physicochemical characteristics of the aquatic system have a direct influence on the types and distribution of aquatic biota [8]. Industrialization and excessive population lead to decrease the physicochemical properties of water due to disposal of human waste, industrial waste and a wide array of synthetic chemicals [9]. Heavy metals are also regarded as serious pollution of aquatic ecosystem because of their environmental persistence and toxicity effects on living organisms [10]. 
In the aquatic environment, the trace elements are partitioned among various environmental components such as water, suspended solids, sediments and biota [11]. The toxicity tests are necessary for water pollution evaluation because chemical and physical measurements alone are not sufficient to assess the potential effects on aquatic biota [12].

Water pollution by microorganisms is now a global concern. Pathogenic bacteria and the presence of antibiotic resistant bacteria in drinking water have become an emerging problem throughout the world [13]. In the disease-prone, humid, tropical region of Bangladesh, outbreaks of diarrhoeal diseases, often on an epidemic scale, are not unusual and the possible role of water-borne pathogens in these outbreaks has been emphasized due to polluted water with pathogenic microorganisms [14]. Among waterborne diseases of bacterial origin typhoid fever, bacillary dysentery and diarrhea are common in Bangladesh [15] [16]. Despite the availability and promotion of the use of safe water sources, water-related diseases remain an important cause of mortality and morbidity in Bangladesh [17]. The emergence of multidrug resistant and ESBL producing $E$. coli has been reported in numerous studies [18]. It becomes a warning barrier to infectious disease management in Bangladesh. The antibiotics resistant genes are either chromosome mediated or plasmid mediated and may be transferred by horizontal gene transfer [19]. Thus the dissemination of antibiotics resistance can be very frequent phenomenon if the resistant bacteria are present in the water. According to the World Health Organization (WHO), the mortality of water associated diseases exceeds 5 million people per year and from these more than $50 \%$ are microbial intestinal infections [20]. In general terms, the greatest microbial risks are associated with ingestion of water that is contaminated with human or animal feces. Waste water discharges in fresh waters and costal seawaters are the major source of fecal microorganisms, including pathogens [21] [22]. The study was carried out to evaluate physicochemical and bacteriological profile of the several water bodies of Nakla Paurosova as well as antibiotic resistance pattern of the bacteria associated with these water bodies and to draw the awareness and concern of the consumers.

\section{Materials and Method}

\subsection{Study Area and Sample Collection}

Thirty water bodies (10 ponds, 10 tube-wells and 10 supply water samples) were randomly selected and collected from Nakla Paurosova, Sherpur district of Bangladesh. The study was carried out from July to November 2018. Approximately, $300 \mathrm{ml}$ of water samples were collected in $500 \mathrm{ml}$ of plastic bottles and before sample collection, all the plastic bottles were properly sterile by autoclave and cleaned by distilled water. Bottles were immersed below the water surface, filled, brought out of the water and properly closed. Then they were properly labeled with sample no, source, date, time etc. and samples were carried to the laboratory within six hours of collection (Figure 1). 


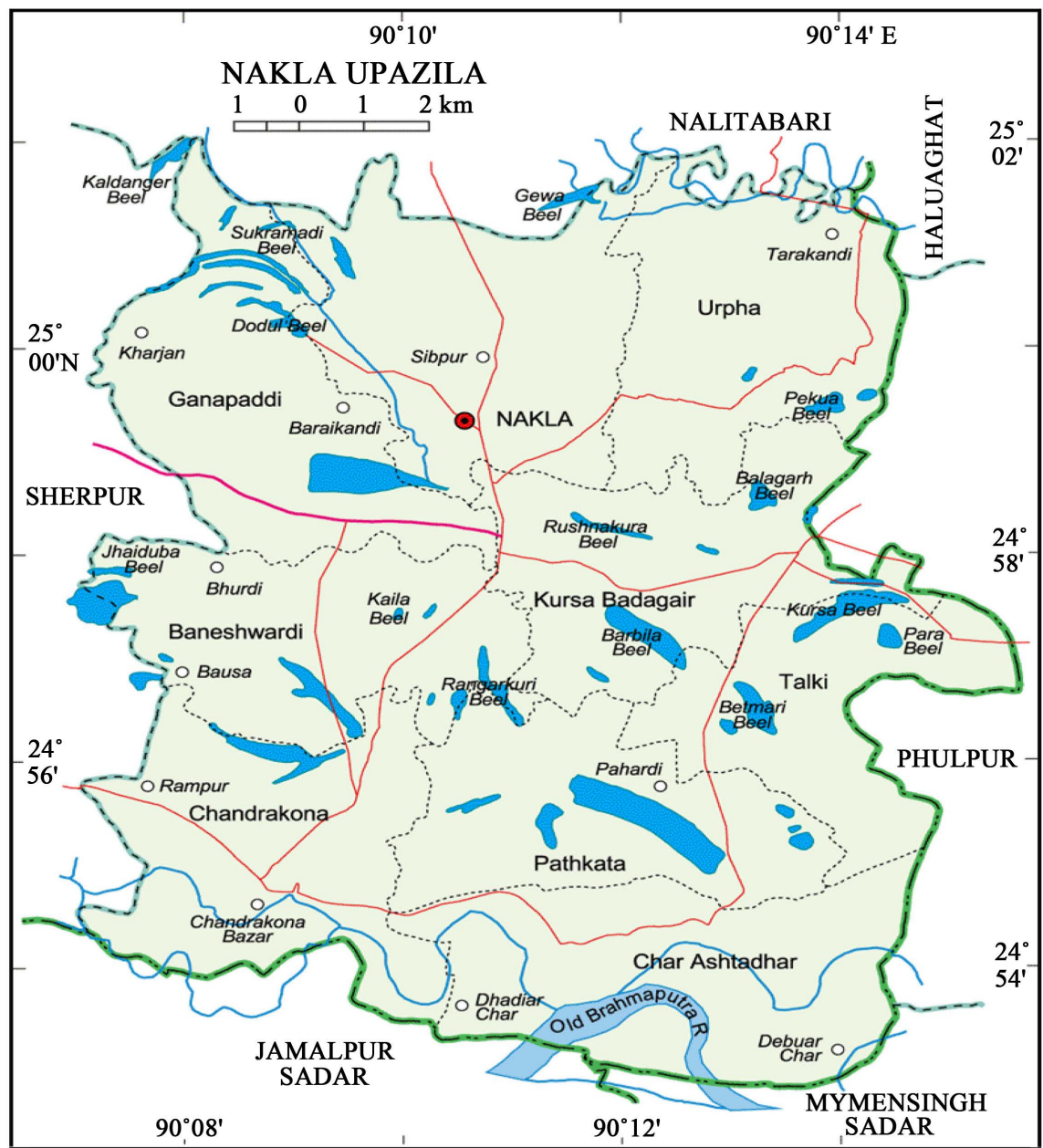

Figure 1. Geographical location of study area.

\subsection{Primary Data Collection}

To investigate the alternation of physicochemical parameters and source of bacterial contamination of different water sources, literature based related primary data (such as-color, odor and surroundings of pond water bodies, deepness of tube-well, types of latrine and its distance from tube-well etc.) were collected with a semi-structured based questionnaire and further analysis [23].

\subsection{Physiochemical Parameters Analysis}

$\mathrm{pH}$ was determined by the digital $\mathrm{pH}$ meter (Hanna instruments). The Dissolved Oxygen (DO) was determined by digital DO meter (Model: D.46974; Taiwan). Digital Electrical Conductivity (EC) meter (Model: HM digital and made in Germany) was used to determine EC. Temperature was measured by the digital thermometer.

\subsection{Detection of Heavy Metal}

Arsenic, Lead and Iron were detected with Detection Kit (Hach Company, USA) and was carried out as the manufacturer's instruction. 


\subsection{Microbial Analysis}

\subsubsection{Total Viable Count (TVC)}

For direct counting, spread plate technique was performed as described previously (APHA, 2003). Firstly, ten-fold serial dilution was carried out of every raw pond water samples. $0.1 \mathrm{ml}$ of each sample is transferred by a micro pipette and spread on agar plates with a sterile bent glass rod. All the plates were inoculated at $37^{\circ} \mathrm{C}$ for 18 hours. Total count is expressed as colony forming unit per $100 \mathrm{ml}$ (cfu/ml). Nutrient Agar media was used as culture media for enumeration of total viable bacteria in sample.

\subsubsection{Heterotrophic Plate Count (HPC) of Drinking Water (Jar and Tube-Wells)}

For the determination of heterotrophic plate count, $100 \mu \mathrm{l}$ of serial tenfold dilution of jar and tube-well water samples were transferred and spread on Plate Count Agar (PCA) media using micro pipette for each dilution. The diluted samples were spread as quickly as possible on the surface of plate count agar with a sterile glass spreader. One sterile glass spreader was used for each plate. The plates were then taken in an incubator at $37^{\circ} \mathrm{C}$ for 18 hours. After incubation at $37^{\circ} \mathrm{C}$ for 18 hours plates exhibiting $30-300$ colonies were counted. The average number of colonies in a particular dilution was multiplied by the dilution factor to obtain the heterotrophic plate count (HPC). The heterotrophic plate count was calculated according to International Organization for Standardization (ISO) (1995). The result of total bacterial count was expressed as the number of organism or colony forming units per 100 milliliter ( $\mathrm{cfu} / 100 \mathrm{ml})$ of water samples.

\subsubsection{Total Coliform Count (TCC)}

Most probable number (MPN) test was done to identify the presence of coliforms in jar and tube-well water samples [24]. In presumptive MPN procedure, 15 lactose broth tubes were inoculated with the water samples. Five tubes received $10 \mathrm{ml}$ of water, 5 tubes received $1 \mathrm{ml}$ of water and 5 tubes received $0.1 \mathrm{ml}$ of water. The number of tubes showing gas production and color change was compared to a standard table developed by American Public Health Association. The number of coliform was the MPN of coliforms per $100 \mathrm{ml}$ of the water sample [25]. For pond water, $0.1 \mathrm{ml}$ of ten-fold serial dilution of every sample was spread with a sterile glass spreader and incubated them at $37^{\circ} \mathrm{C}$ for 18 hours. After incubation the colony was counted by standard plate count method described as before.

\subsubsection{Detection of Fecal Coliforms}

The positive presumptive cultures were transferred to lactose broth, which is specific for fecal coliform bacteria. Any presumptive tube which showed gas production after $24( \pm 2)$ hours incubation at $44.5^{\circ} \mathrm{C}\left( \pm 0.2^{\circ} \mathrm{C}\right)$, confirmed the presence of fecal coliform bacteria in that tube and was recorded as positive [26]. 


\subsubsection{Isolation of Pathogenic Bacteria}

For the identification of pathogenic bacteria, $100 \mu \mathrm{l}$ of each sample were transferred into Thiosulfate Citrate Bile Salts Sucrose Agar (TCBS) media, Eosin methylene blue Agar (EMB) and Shigella Salmonella Agar (SS) media with ten-fold dilution. The diluted samples were spread as quickly on the surface of the plate with a sterile glass spreader and incubated at $37^{\circ} \mathrm{C}$ for overnight. The presence of pathogenic bacteria were observed and counted.

\subsubsection{Cultural and Biochemical Examination of Samples}

The cultural examination of water samples for bacteriological analysis was done according to the standard method by ICMSF [27]. The examination followed detail study of colony characteristics including the morphological and biochemical properties. In order to find out different types of microorganisms in water samples, different kinds of bacterial colonies were isolated in pure culture from the plate count agar (PCA), MacConkey agar (MCA), SS agar, TCBS agar and subsequently identified according to the methods described by Krieg [28]. Gram staining and biochemical reaction were performed for further confirmation of presumptively identified bacteria according to Bergey's Manual Determinative Bacteriology [29]. Among these 15 samples 12 kinds of biochemical test such as Kligler Iron Agar (KIA), Motility Indole Urease (MIU), Citrate, Voges Proskauer (VP), Oxidase, Catalase, Mannitol, Starch, Methyl Red (MR), Glucose, Lactose, Eosin Methylene Blue (EMB) were performed.

\subsubsection{Antibiotic Sensitivity Test}

Antibiotic susceptibility test was performed by disk diffusion method (Kirby-Baur method) using the commercially available antibiotic disk on Mullar-Hinton agar to assess the susceptibility and resistance pattern of the isolates [30]. 10 different types of common antibiotic disks (Himedia, India and Oxoid Ltd. England) were used in this study.

\subsection{Evaluation of Public Health Impact}

A field investigation and semi-structured questionnaire based survey was conducted among randomly selected 300 respondents (10 from each sampling sight, $50 \%$ male and $50 \%$ female) of the study area to determine the health status of people who were the consumers of these water.

\subsection{Statistical Analysis}

MS Excel 2013 was used for data analysis and presentation of graphs.

\section{Results and Discussion}

\subsection{Analysis of Pond Surroundings}

In Bangladesh, the major causes of contamination of surface water are dumping of domestic waste, cattle washing, connection with drains and opening of the latrine into water bodies etc. In this study, among ten ponds, only two (pond-4 
and pond-7) were connected with drains, four (pond-2, pond-4, pond-7 and pond-8) were polluted directly by dumping of waste, $50 \%$ (pond-1, pond-2, pond-5, pond-7 and pond-9) was used for washing of cattle by the people around it and $20 \%$ (pond-4 and pond-8) was contaminated with direct fecal coliforms by the opening of latrines into these water bodies (Figure 2).

Due to dumping of domestic, untreated industrial and municipal wastes, the majority numbers of water reservoirs in Bangladesh are becoming hazardous for human, animal and aquatic lives [31]. On the other hand, cattle washing on ponds degrade water quality and sanctions concern microbial contaminants which are threatening to human health and ecological life [32].

\subsection{Surrounding Environment of Tube-Wells}

The microbial quality of tube-wells water depends on the deepness of tube-wells, its distance from latrine and the latrine's condition. Here, the deepness of 10 tube-wells were varies from 60 to 105 feet and the mean deepness was 85.5 feet. The distance from latrine to tube-wells was counted about 9 to 36 feet and the mean distance was about 20 feet. Three types of latrine were found by considering latrine condition; four were direct pit, three were offset and three were soak with septic tank (SWST) (Figure 3). In previous studies it was found that, low deepness of tube wells and less distance from latrine indirectly related to the microbial contamination of the water of these sources [33].

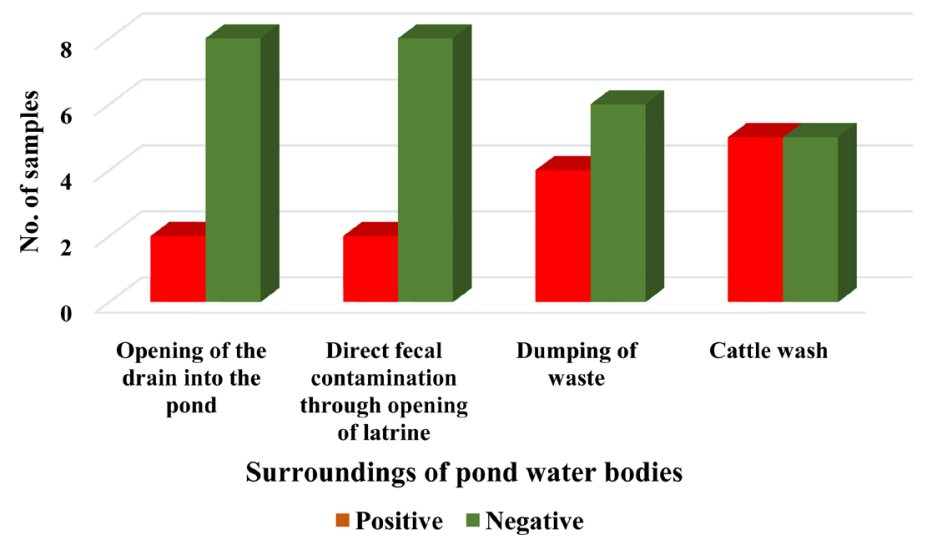

Figure 2. Surroundings of pond water.

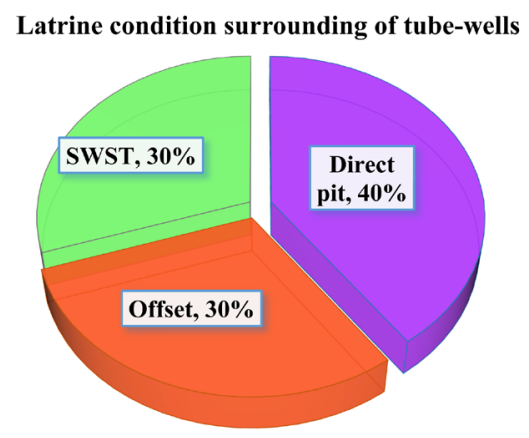

Figure 3. Surrounding of tube-wells. 


\subsection{Physiochemical Parameters Analysis}

\subsubsection{Color and Odor of Pond Water}

The color and odor of pond water were observed visually because it is an important premier indicator for investigating water quality which indicates its suitability for survival of fishes or other aquatic creatures, and for domestic works. According to the guidelines of WHO (2004) for water quality, the color level below 15 true color units (TCU) are acceptable for most aquatic inhabitants and above 15 TCU are detected by naked eyes [34]. In this study, about $30 \%$ of pond were appeared turbid (pond-4, pond-7 and pond-8) where, the other 30\% (pond-1, pond-5, and pond-9) were light green, rest of them were deep green (20\%) and brown (20\%) in color (Figure 4). The odor of water is directly proportional to the level of contamination. Among 10 samples, about $60 \%$ were smelling normal and $40 \%$ having bad odor (Figure 5). Bad odor can be resulted from over bacterial growth along with discharging of domestic and industrial waste from the surrounding area [35].

\section{Colors of pond water}

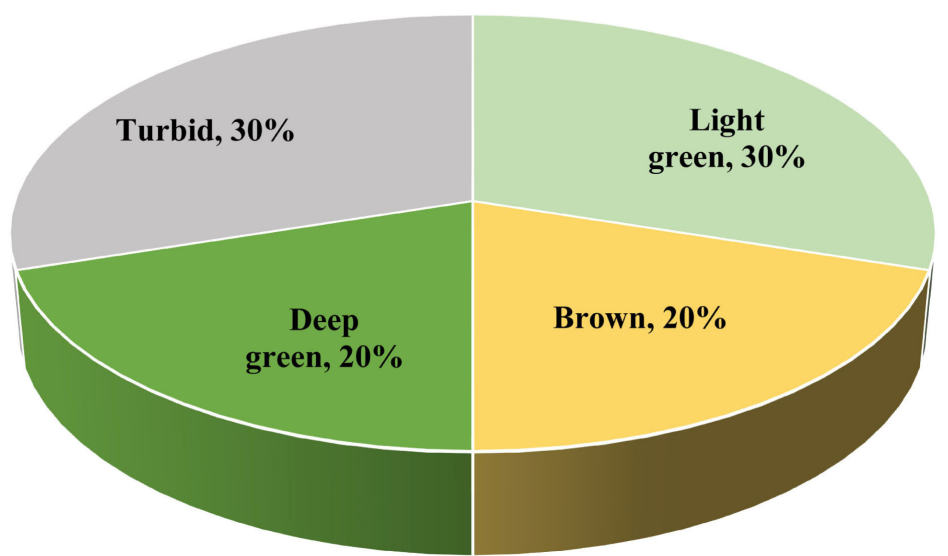

Figure 4. Colors of pond water samples.

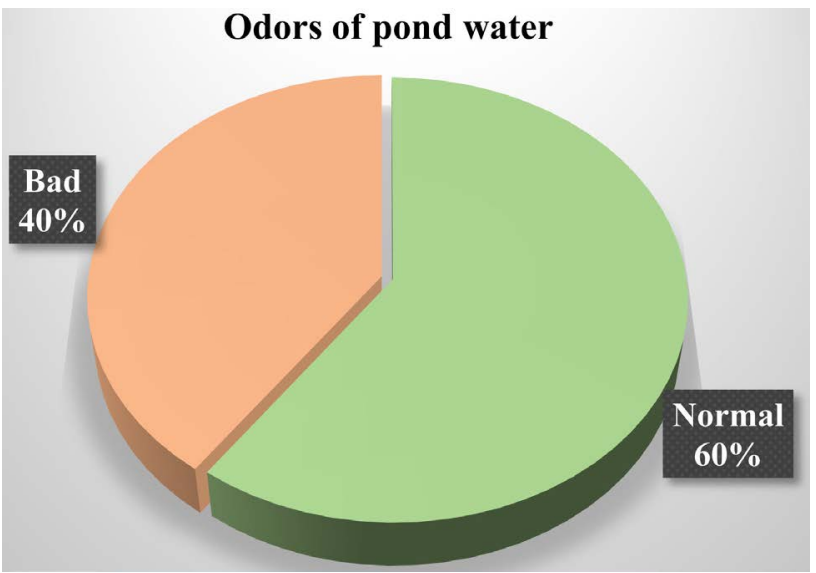

Figure 5. Odors of pond water. 


\subsubsection{Temperature of Pond Water}

The variation of water temperature generally depends on season, geographic location, sampling time and temperature of effluents [36]. The temperature of ten pond water bodies was founded ranging from $27.8^{\circ} \mathrm{C}$ to $29.5^{\circ} \mathrm{C}$, and the mean was $28.6^{\circ} \mathrm{C}$. In another similar study conducted in Tangail area, recorded the temperature of ponds water range from $17.9^{\circ} \mathrm{C}$ to $23.0^{\circ} \mathrm{C}$ and the average value was $20.7^{\circ} \mathrm{C}$ [37]. Both of these results are closely related to the optimum temperature $\left(20^{\circ} \mathrm{C}-30^{\circ} \mathrm{C}\right)$ that favorable for living of aquatic habitants [38].

\subsubsection{The $\mathrm{pH}$ of Water Bodies}

$\mathrm{pH}$ is one of the most important attribute of any aquatic system and it can be changed due to alteration of physicochemical and environmental factors of water [39] [40]. The mean $\mathrm{pH}$ of pond, jar and tube-well water was recorded as 6.96, 6.93 and 7.1 respectively. The highest $\mathrm{pH}$ was 7.55 (Pond-3), 7.55 (Jar-6), 7.75 (TW-3) and lowest was 6.37 (Pond-8), 6.26 (Jar-7), 6.69 (TW-9) for pond, jar and tube-well water in some respects (Figure 6). According to WHO's standard, an appropriate range of $\mathrm{pH}$ for drinking water is 6.5 - 8.5 [41]. The average $\mathrm{pH}$ of jar and tube-well water of the study area was within the standard limit. Some previous works reported the mean $\mathrm{pH}$ of supply water was 6.84 in Sherpur, Bangladesh [33] where the average $\mathrm{pH}$ of drinking water was 6.27 at rural area of Bangladesh [42]. On the other hand, a study on pond water quality of Tangail area found the average $\mathrm{pH}$ was 7.68 [37]. $\mathrm{pH}$ range 7.5 to 8.4 is good for the growth of algae, 6.0 to 7.2 is optimum for laying fish [43], 6 to 8 is good for growth and reproduction of fish species, but pH below 5 or as high as 9 to 11 do not allow fishes to reproduce, and also cause slow growth [44].

This current work recorded the $\mathrm{pH}$ of ponds water as slightly alkaline, which may due to inorganic sediments or domestic and agricultural wastes disposed in these water bodies.

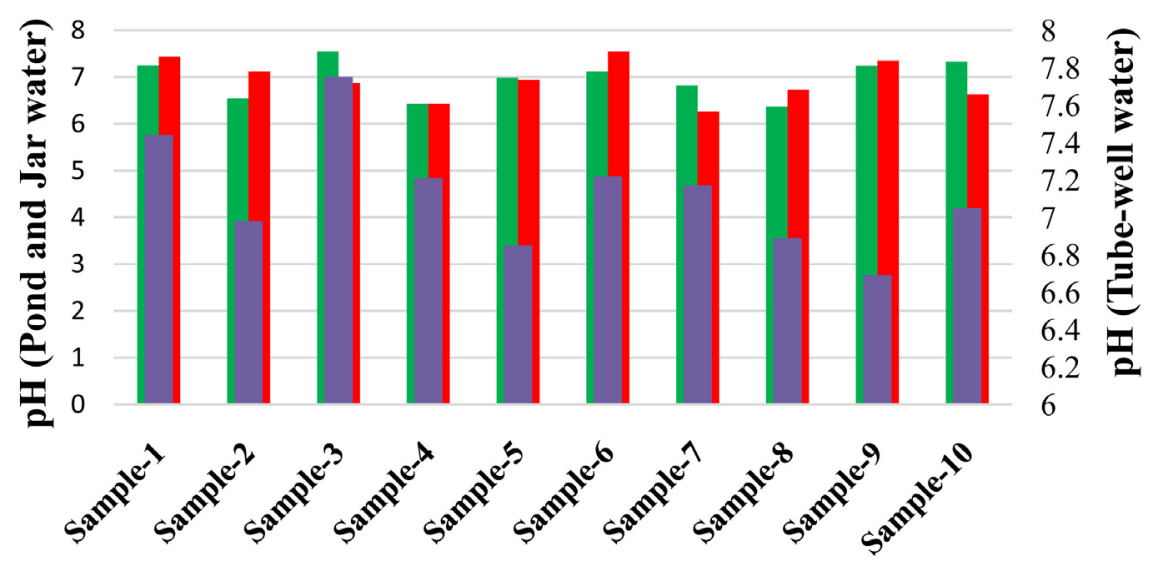

Water bodies

• Pond water $\square$ Jar water $\square$ Tube- well water

Figure 6. pH of all water bodies. 


\subsubsection{Dissolved Oxygen (DO) of Water Bodies}

Dissolved oxygen is the only sources of oxygen for respiration of aquatic creature. Insufficient and imbalance DO may lead to cause of sudden death of these creature. The average DO of pond, jar and tube-well water was determined as $4.3,3.7$ and $5.8 \mathrm{mg} / \mathrm{l}$. The maximum concentration of DO was $5.4 \mathrm{mg} / \mathrm{l}$ (pond-6), $4.3 \mathrm{mg} / \mathrm{l}$ (jar-6), $7.1 \mathrm{mg} / \mathrm{l}$ (TW-3) and the minimum was $3.4 \mathrm{mg} / \mathrm{l}$ (pond-8), $3.1 \mathrm{mg} / \mathrm{l}$ (jar-3), $4.9 \mathrm{mg} / \mathrm{l}$ (TW-9) for pond, jar and tube-well water relatively (Figure 7). Department of Environment, Ministry of Environment and Forest, Government Republic of Bangladesh set the standard value of DO for drinking water for Bangladesh as $6 \mathrm{mg} / \mathrm{l}$ or more [45]. Previous studies found the average DO of pond water was $5.23 \mathrm{mg} / \mathrm{l}$ in Tangail area [37] and $7.7 \mathrm{mg} / \mathrm{l}$ in Thakurgaon Sadar Upazila [46]. The mean DO contents of supply water and average DO of tube-well water in Fulbaria, Bangladesh were reported as $3.1 \mathrm{mg} / \mathrm{l}$ and $3.1 \mathrm{mg} / \mathrm{l}$ respectively [33]. The average DO of water bodies in study area was below the satisfactory level, so why pond water was not suitable for fish production and aquatic eco-system where tube-wells or tap water for drinking. Due to the pollution of the surface water, lack of proper treatment or excessive water treatment for purification, and the over growth of microorganisms in water bodies may be the possible causes of low level of DO.

\subsubsection{Electrical Conductivity (EC)}

Electrical conductivity (EC) is a quantification of the capability of a liquid to conduct an electric current. Water shows important conductivity when inorganic cations and anions (such as sodium, calcium, magnesium, aluminum, chloride, nitrate, sulfate, phosphate etc.) were dissolved [47]. The highest and lowest EC was $341 \mu \mathrm{S} / \mathrm{cm}$ (pond-7) and $196 \mu \mathrm{S} / \mathrm{cm}$ (pond-10), and the average was $266.3 \mu \mathrm{S} / \mathrm{cm}$ in pond water.

The maximum and minimum EC was $610 \mu \mathrm{S} / \mathrm{cm}$ (Jar 6) and $417 \mu \mathrm{S} / \mathrm{cm}$ (Jar 9) in jar water and the average was $495.2 \mu \mathrm{S} / \mathrm{cm}$. On the other hand, the highest and lowest EC of tube-well water was $965 \mu \mathrm{S} / \mathrm{cm}$ (TW 6) and $635 \mu \mathrm{S} / \mathrm{cm}$ (TW 5)

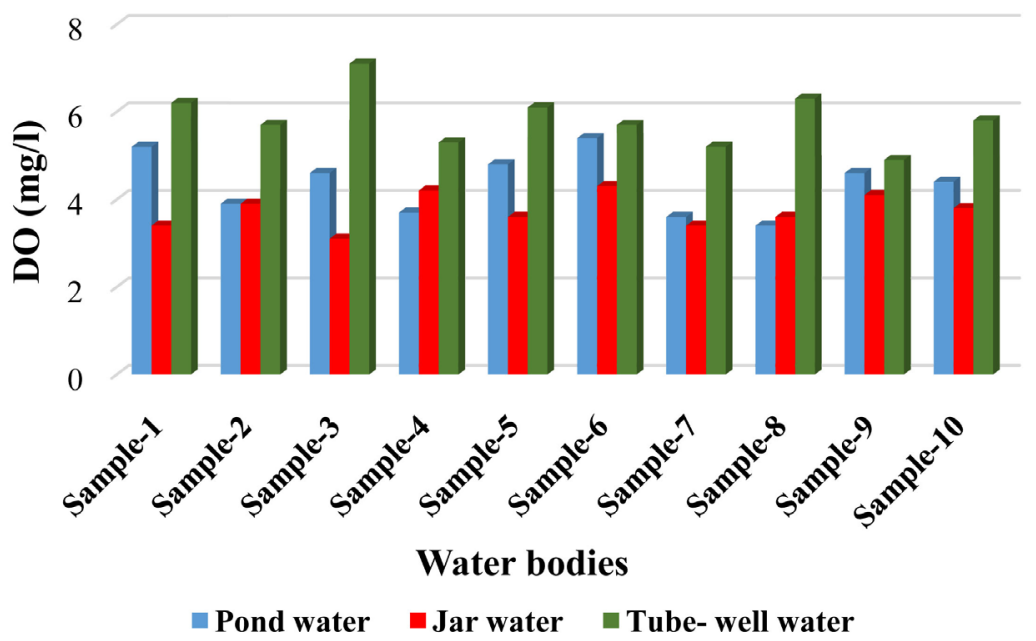

Figure 7. Values of DO of all water bodies. 
where the average was $760.5 \mu \mathrm{S} / \mathrm{cm}$ (Figure 8). The average EC of pond water of Thakurgaon Sadar Upazila was reported as $145 \mu \mathrm{S} / \mathrm{cm}$ [46] and water with an EC value of $0-750 \mu \mathrm{S} / \mathrm{cm}$ is considered as excellent for irrigation [48]. A study reported the EC value of the bottled waters of Dhaka city, Bangladesh was 38.4 to $493.0 \mu \mathrm{S} / \mathrm{cm}$ and the mean was $173.3 \mu \mathrm{S} / \mathrm{cm}$ [49]. The maximum permissible limit of EC in Bangladesh is $1200 \mu \mathrm{S} / \mathrm{cm}$ for safe drinking water [45].

\subsection{Presence of Heavy Metals}

The presence of heavy metal in drinking water may lead to complications of kidney, and in pond water may cause ionic imbalance. None of these three heavy metals, Arsenic ( $\mathrm{As})$, Lead $(\mathrm{Pb})$ and Iron $(\mathrm{Fe})$ were detected in both pond and jar water, but iron was detected in six samples in tube-wells where only one was positive to arsenic (Figure 9). But Lead $(\mathrm{Pb})$ and Iron $(\mathrm{Fe})$ were detected in pond water by another study conducted in Ashulia area, Bangladesh [50]. A recent study showed that arsenic was not detected in jar water of Dhaka city but iron was in acceptable limit [49]. Most of the tube-well water of Kushtia district, Bangladesh were positive to arsenic and iron, but majority of them were within reasonable limit [51].

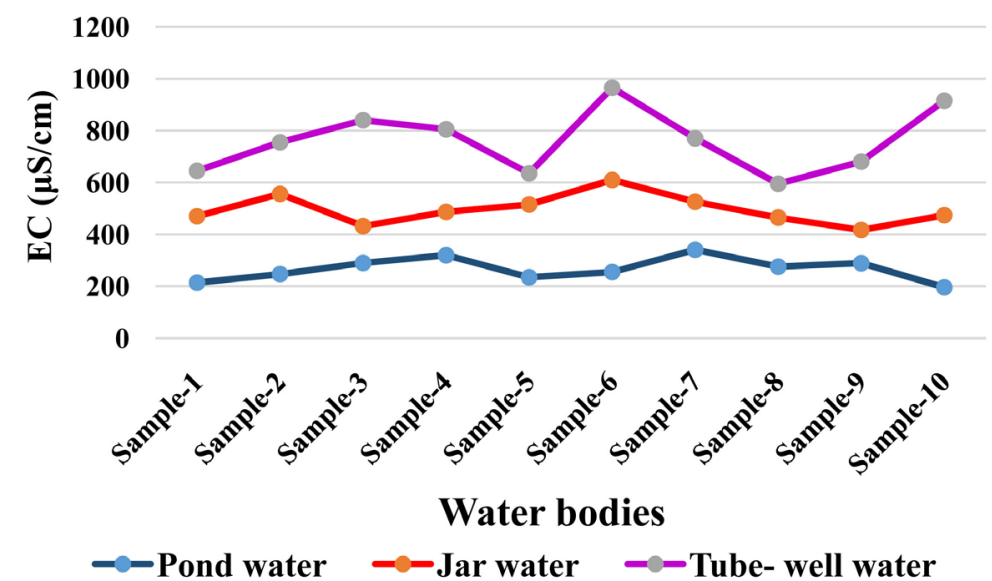

Figure 8. Electrical conductivity of water bodies.

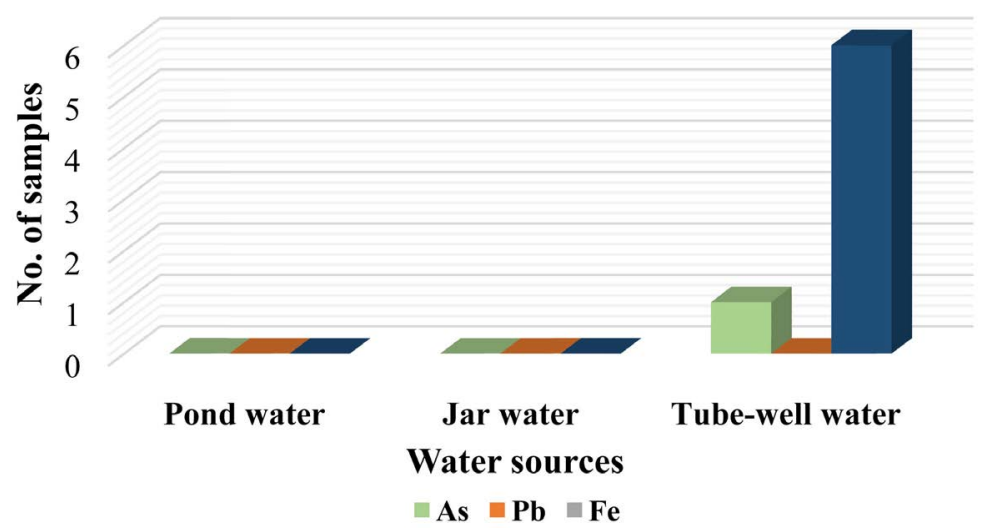

Figure 9. Presence of heavy metals in water bodies. 


\subsection{Microbiological Quality Analysis}

\subsubsection{Total Viable Count (TVC) of Pond Water}

Total viable count (TVC) indicates a quantitative estimate of the concentration of microorganisms in a sample. Among ten pond water samples, the highest TVC count was $4.4 \times 10^{15} \mathrm{cfu} / 100 \mathrm{ml}$ (pond-8) and the lowest count was $2.7 \times 10^{7}$ $\mathrm{cfu} / 100 \mathrm{ml}$ (pond-3) (Figure 10). A previous study reported that the average TVC of pond water in Dhaka university campus was $2.7 \times 10^{6} \mathrm{cfu} / 100 \mathrm{ml}$ [52]. Surface water is the source of a variety of microorganisms for its surrounding environment. Due to the connection of drain and latrine in pond water and dumping of different contaminated wastes may be the prime cause of these contaminants.

\subsubsection{Heterotrophic Plate Count (HPC) of Drinking Water}

Heterotrophic plate count (HPC) is a method that measures colony formation on culture media of heterotrophic bacteria of a particular sample. It is the measurement of bacteriological quality of drinking water in public, semi-public and private water supply systems. In case of jar water, the highest HPC count was 3.1 $\times 10^{5} \mathrm{cfu} / 100 \mathrm{ml}$ (jar-4) and the lowest count was $1.8 \times 10^{5} \mathrm{cfu} / 100 \mathrm{ml}$ (jar-10). The mean HPC of jar water was $2.4 \times 10^{5} \mathrm{cfu} / 100 \mathrm{ml}$. But in tube-well water the count was $2.6 \times 10^{5} \mathrm{cfu} / 100 \mathrm{ml}$ to $1.3 \times 10^{5} \mathrm{cfu} / 100 \mathrm{ml}$ and the average count was $1.8 \times 10^{5} \mathrm{cfu} / 100 \mathrm{ml}$ (Figure 11). The average HPC of tap water of Jamalpur district and tube-well water in Tangail district was reported as $4.2 \times 10^{7} \mathrm{cfu} / 100 \mathrm{ml}$ and $2.7 \times 10^{7} \mathrm{cfu} / 100 \mathrm{ml}$ respectively [53]. According to WHO guideline, the values of HPC should remain within $1.0 \times 10^{3} \mathrm{cfu} / 100 \mathrm{ml}$ for drinking water but all determined values were above than the standard value [42]. Lack of appropriate treatment of supply water, unhygienic bottle condition, poor sanitation condition and leakage of pipes of tube-wells may be the leading causes of contamination of drinking water in the study area.

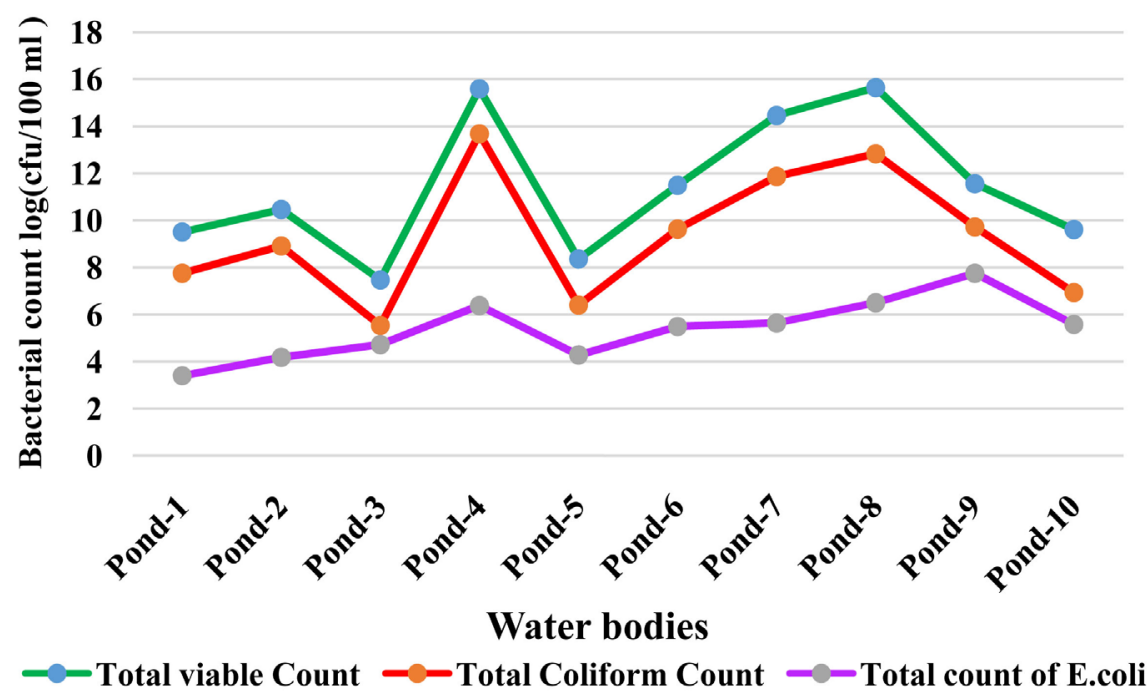

Figure 10. TVC, TCC and total E. coli count of pond water. 

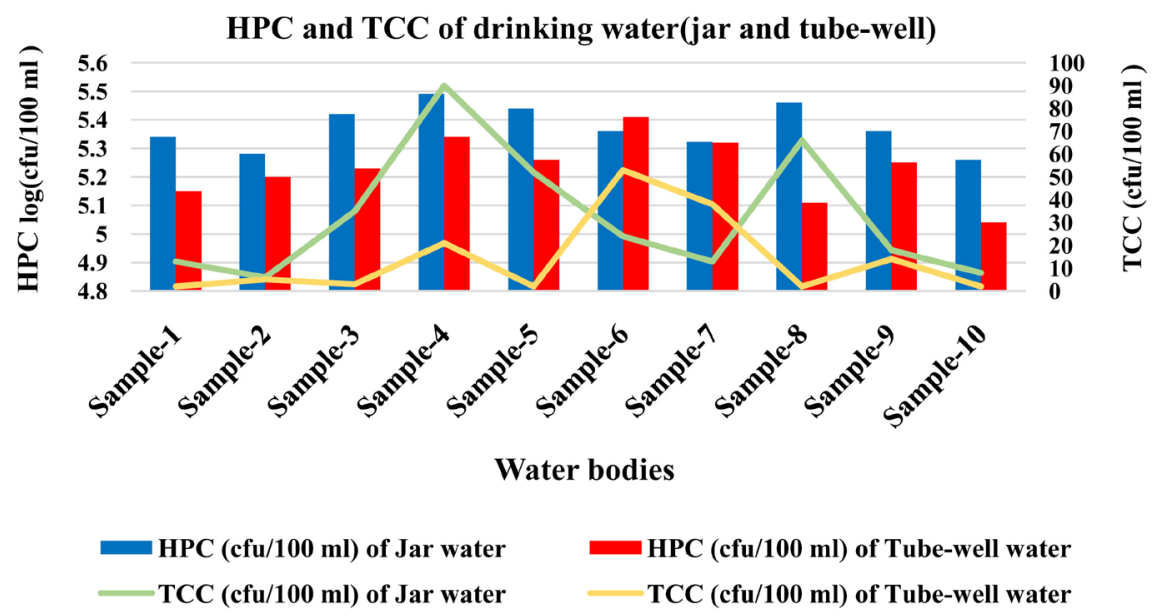

Figure 11. HPC and TCC of drinking water.

\subsubsection{Total Coliform Count}

Coliform bacteria is a group of pathogenic bacterial organisms which may present in food, water, soil and aquatic environment. Total coliform count used as an indicator to determine the microbial quality of treated water and it's suitability for human consumption or not. The presence of excessive coliform bacteria suggests that disease causing pathogenic bacteria or fecal coliform may contaminate water sample [54]. In pond water, the lowest value of TCC was counted as $3.4 \times 10^{5} \mathrm{cfu} / 100 \mathrm{ml}$ (Pond-3) and the highest was $4.8 \times 10^{13} \mathrm{cfu} / 100 \mathrm{ml}$ (Pond-4) where the mean value was $2.5 \times 10^{6} \mathrm{cfu} / 100 \mathrm{ml}$ (Figure 10). In a previous study, the average values of TCC was $4.5 \times 10^{18} \mathrm{cfu} / 100 \mathrm{ml}$ in different surface water of Dhaka, Bangladesh [55] and many other studies also support the similar result regarding TCC [52] [56] [57]. In jar water, the highest number of coliform was 90 (Jar-6), lowest was 6 (Jar-2) and the average was about 33 (Figure 11). A past study reported that, the range of total coliform count was 33 $\mathrm{cfu} / \mathrm{ml}$ to $1.0 \times 10^{3} \mathrm{cfu} / \mathrm{ml}$ in house tap water at Dhaka, Bangladesh [58]. In tube well water, the lowest number of coliform was counted as $\leq 2$ (TW-1, 5, 10) and the highest number was 53 (TW-6) where the mean was about 14 (Figure 11). A previous study on tube-well water of Magura district in Bangladesh reported that all underground water sources contained total coliforms ranging from $\leq 2$ $\mathrm{cfu} / 100 \mathrm{ml}$ to $\geq 100 \mathrm{cfu} / 100 \mathrm{ml}$ [59]. Connection of the drains with pond, opening of the latrine on it or directly fecal contamination by different faces etc. are the most probable vital causes for the presence of coliform in pond water.

On the other hand, coliform contamination of tube-well water may occurred due to less distance of latrine from tube-well, low deepness of tube-well, latrine's surrounding condition, personal unhygiene, cross-contamination or pre-existing microbial contaminants present in handle or upper surface of tube-well.

\subsubsection{Presence of Fecal Coliform}

Fecal coliform is a large sub-group of coliform bacteria that exist in faeces. Certain types of fecal coliforms can be found naturally on plants and soils [55]. Fecal coliforms may detect in drinking water due to the contamination of sewage or 
other sources of fecal matter [54]. It may cause severe gastrointestinal illness, however their presence in drinking water may indicate the presence of disease-causing organisms [60]. In this study, fecal coliform were detected in all ponds water, 4 jar water (out of 10) and 3 tube-well water samples (out of 10) (Figure 12). A study reported the similar result of pond water at Dhaka, Bangladesh [61] where another study found that only $18.8 \%$ tube-well water and $16.6 \%$ of supplied water samples were free of fecal coliform [62]. Presence of fecal coliform in these sources indicate inappropriate hygienic practice, inadequate proper sanitation system and lack of appropriate fecal management, which are now becoming matter of concern and damning news for public health.

\subsubsection{Biochemical Test for Presumptive Conformation of Bacterial} Species

Four types of distinct bacterial species (E. coli, Salmonella spp., Shigella spp. and Vibrio spp.) were isolated and identified by observing different morphological characteristics on selective media and further confirmed with standard short Biochemical test (Table 1).
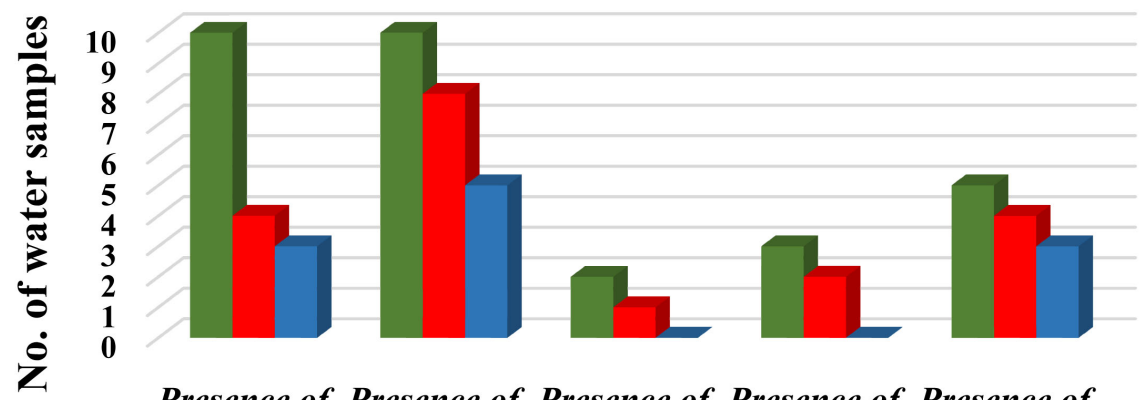

\section{Presence of Presence of Presence of Presence of Presence of fecal E. coli Shigella Salmonella Vibriospp. coliform spp. spp.}

Presence of Bacterial spp.

- Pond water Jar water $\quad$ Tube-well water

Figure 12. Presence of pathogenic bacteria.

Table 1. Reaction of biochemical test.

\begin{tabular}{|c|c|c|c|c|c|c|c|c|c|c|c|c|c|c|c|c|c|}
\hline \multirow{3}{*}{ 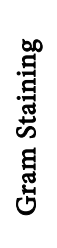 } & \multicolumn{16}{|c|}{ Biochemical reaction } & \multirow{3}{*}{ 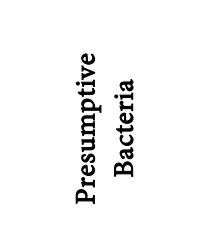 } \\
\hline & \multirow{2}{*}{ 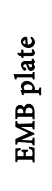 } & \multicolumn{3}{|c|}{ KIA } & \multicolumn{3}{|c|}{ MIU } & \multirow[b]{2}{*}{ 我莡 } & \multirow[b]{2}{*}{ 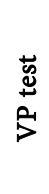 } & \multirow[b]{2}{*}{ 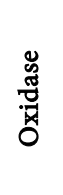 } & \multirow[b]{2}{*}{ 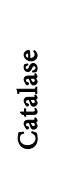 } & \multirow[b]{2}{*}{ 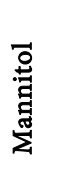 } & \multirow[b]{2}{*}{ 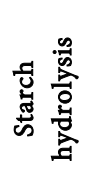 } & \multirow{2}{*}{ 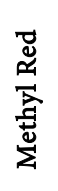 } & \multirow[b]{2}{*}{ 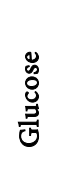 } & \multirow{2}{*}{ 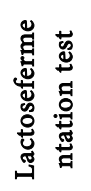 } & \\
\hline & & 荳 & 泀 & స్ & 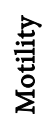 & $\underset{\Xi}{\stackrel{\Xi}{g}}$ & 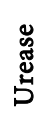 & & & & & & & & & & \\
\hline$-\mathrm{Ve}$ & + & $\mathrm{A}$ & A & + & + & + & + & - & - & - & + & A & - & + & AG & + & E. coli \\
\hline$-\mathrm{Ve}$ & - & K & A & G & + & + & - & + & - & + & + & + & + & + & + & - & Vibrio spp. \\
\hline$-\mathrm{Ve}$ & - & K & A & G & + & - & + & + & - & - & - & A & - & + & - & - & Salmonella spp. \\
\hline$-\mathrm{Ve}$ & - & K & A & - & - & - & - & - & - & - & + & - & - & + & + & - & Shigella spp. \\
\hline
\end{tabular}

$\mathrm{K}=$ Alkaline $, \mathrm{A}=\mathrm{Acid}, \mathrm{G}=\mathrm{Gas}, \mathrm{AG}=$ Acid and Gas, $+=$ Presence,$-=$ Absence . 


\subsubsection{Escherichia coli Count}

Presence of E. coli in water is a common phenomenon but a high count of $E$. coli indicates that the water is unfit for drinking and any kinds of household works. High number of $E$. coli also indicates probable recent fecal contamination and there is a greater risk that pathogenic E. coli may present [63]. E. coli causes severe gastrointestinal-tract related complications like diarrhea, dysentery, urinary tract infections, pneumonia and even meningitis [64]. There is a clear relationship between the concentration of $E$. coli in a particular water sample and the possibility of onset gastrointestinal complications in human that exposed to the water through drinking [65]. This study has exposed the presence of $E$. coli in pond water where the maximum concentration was $5.7 \times 10^{7} \mathrm{cfu} / 100 \mathrm{ml}$ (Pond-9) and the minimum was $1.5 \times 10^{4} \mathrm{cfu} / 100 \mathrm{ml}$ (Pond-2). The mean concentration of E. coli was $6.4 \times 10^{6} \mathrm{cfu} / 100 \mathrm{ml}$ (Figure 11) and it exceeded the EPA's recommended limit [60]. A study reported that the average concentration of $E$. coli at pond water of Dhaka city was $2.12 \times 10^{2} \mathrm{cfu} / 100 \mathrm{ml}$ and also found the presence of E. coli at household water [66]. In our study area, $80 \%$ of jar and $50 \%$ of tube-well water samples were contaminated with E. coli. Another study reported that, about $40 \%$ of tube-well water of Noakhali district, Bangladesh contaminated with E. coli [67].

\subsubsection{Presence of Shigella Spp.}

Shigella spp. is an inhabitant of the intestinal tract of human and other primates [68]. It is typically spread through fecal-contaminated drinking water, food or by direct contact with an infected person. In water, Shigella spp. is able to survive a few days at room temperature and this survival reason favors the transmission through water [69]. A large number of waterborne outbreaks have been occurred because of shigellosis over the past years [70]. Among 30 water bodies of the study area, $20 \%$ of pond and $10 \%$ of jar water samples were contaminated with Shigella spp. and tube-well water was free from this organism (Figure 12). Shigella spp. can survive transit through the stomach since they are less susceptible to acid than other bacteria; for this reason, as few as 10 to 100 organisms can cause disease [71]. Jar with contaminants and cross contamination during personal handling can be considerable reason for contamination of jar water. Open latrine and drainages were the major source of fecal contamination of pond water that can break out serious shigellosis among this water consumer.

\subsubsection{Presence of Salmonella Spp.}

Salmonella spp. cannot multiply significantly in the natural environment, but they can survive several weeks in nutrients rich water and soil with favorable temperature, humidity, and $\mathrm{pH}$ [72]. The intestinal tract of human and animals are the major habitat of Salmonella spp. that causes four clinical manifestations: gastroenteritis, bacteremia, typhoid fever, and carrier state in persons who had been previously infected [73]. Here, 30\% of pond and 20\% of jar water were contaminated with Salmonella spp. tube-well water were free from Salmonella spp. (Figure 12) that is similar with another study [74]. Microbiological study 
on supply water in Dhaka city reported that, 50\% of supplied water were contaminated with Salmonella spp. [75].

\subsubsection{Vibrio Spp. Count}

Vibrio is a genus of ubiquitous bacteria found in a wide variety of aquatic and marine habitats [76]. Vibrio cholerae caused cholera which is a major public health problem in developing countries like Bangladesh. It is a waterborne pathogen and transmitted through aquatic sources or the feces of an infected person [77]. Several Vibrio species can infect human and $V$. cholerae is the most pathogenic among of these species [78] [79]. Vibrio spp. was detected in 50\% of pond water in this study where their count was $1.2 \times 10^{3}$ to $5.7 \times 10^{4} \mathrm{cfu} / 100 \mathrm{ml}$, and the average was $1.3 \times 10^{4} \mathrm{cfu} / 100 \mathrm{ml}$. The presence of Vibrio spp. was detected in $40 \%$ of jar and $30 \%$ of tube-well water samples (Figure 12). A study reported that about 58\% pond water were contaminated with Vibrio spp. in Khulna Division, Bangladesh [80]. In another case, about 27\% Vibrio spp. were isolated in Dhaka city and $25 \%$ of tube-well water were contaminated with it at coastal area, Bangladesh [81] [82]. Contamination of tube-well water appears related to a number of factors, including proximity of latrines or drains to the tube wells, tube well depth or method of completion.

\subsection{Antibiotic Resistance Pattern}

A great deal of health threat may arise through the spreading of the antibiotic resistance to normal flora or creating the environment which would be favorable for opportunistic pathogens. Among the isolated organisms, E. coli was highly resistance to Ampicillin (70\%), Amoxicillin (70\%) and showed 100\% sensitivity to Ciprofloxacin, $80 \%$ to Norfloxacin, $70 \%$ to both Streptomycin and Azithromycin, and $60 \%$ to Tetracycline and Erythromycin as well (Figure 13).

Shigella spp. was highly resistance to Ampicillin (90\%) and highly sensitive to Ciprofloxacin (70\%) (Figure 14) where Salmonella spp. was $100 \%$ resistance to Ampicillin and highly sensitive to Ciprofloxacin (60\%) (Figure 15). On the other hand, Vibrio spp. was highly resistance to Amoxicillin (60\%) and highly sensitive to Ciprofloxacin (60\%) (Figure 16). Some previous studies reported that

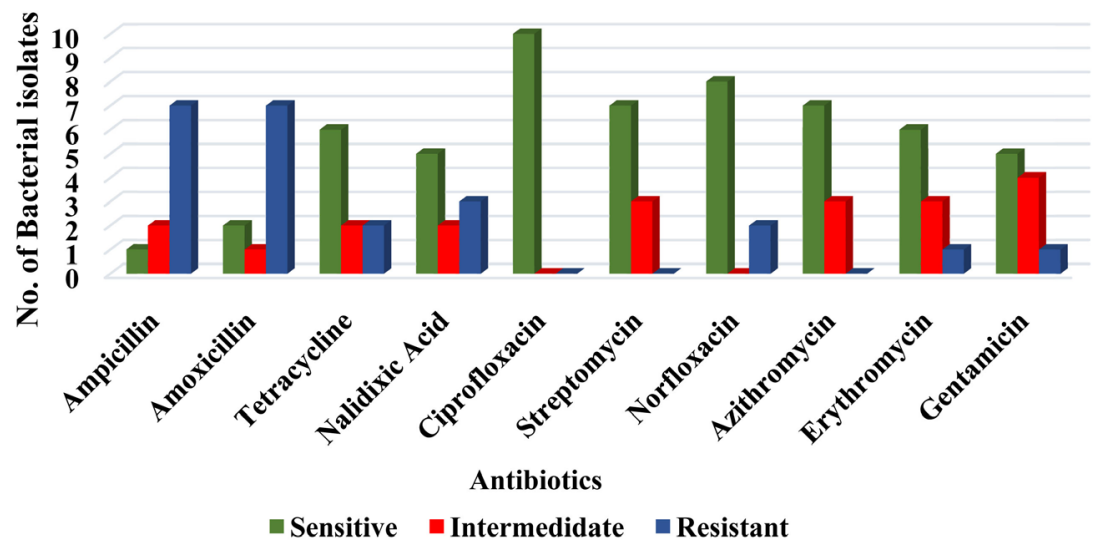

Figure 13. Antibiotic resistance pattern of E. coli. 


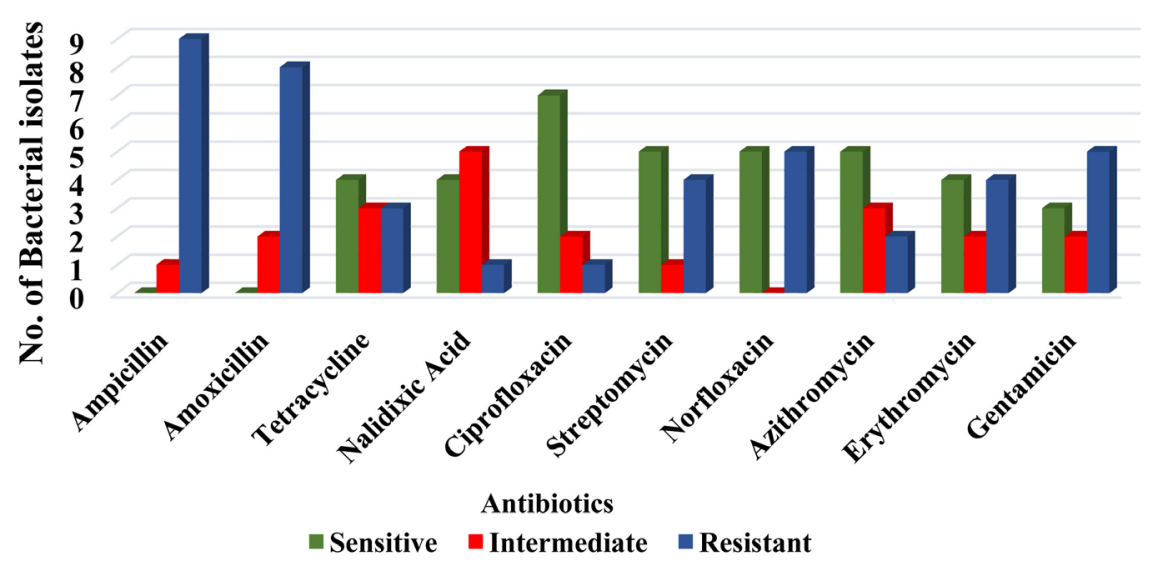

Figure 14. Antibiotic resistance pattern of Shigella spp.

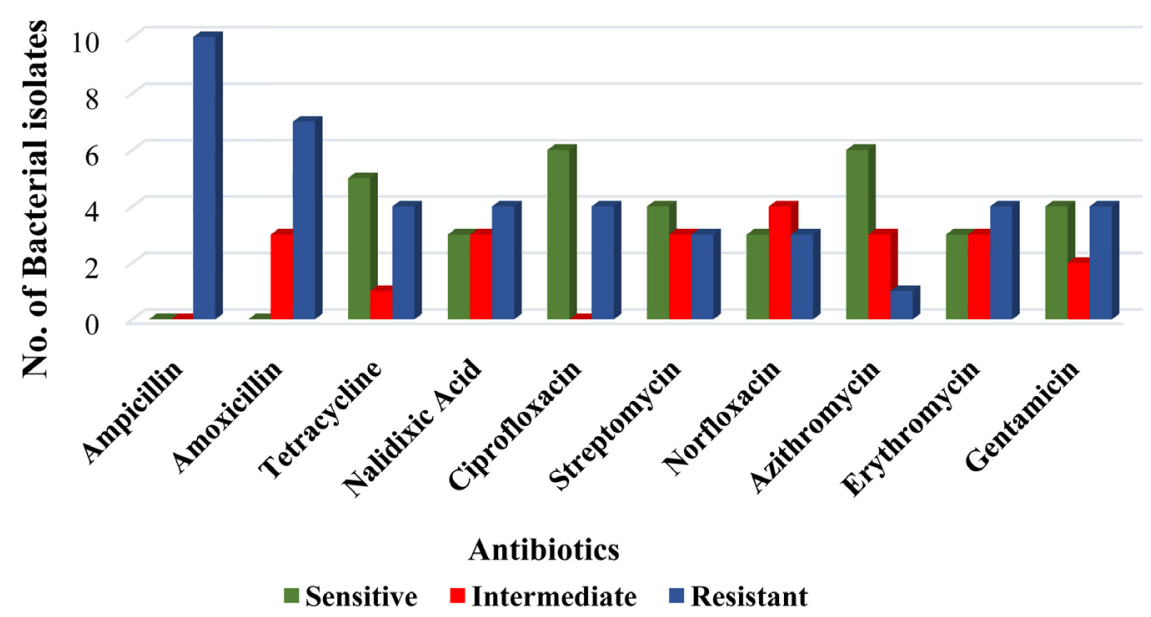

Figure 15. Antibiotic resistance pattern of Salmonella spp.

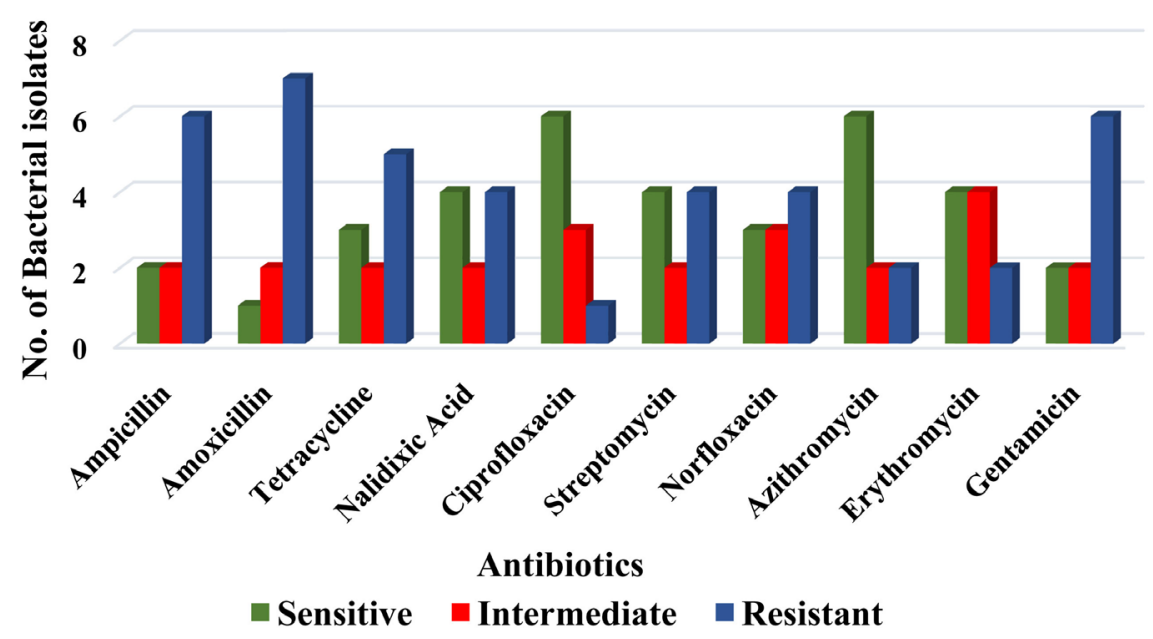

Figure 16. Antibiotic resistance pattern of Vibrio spp.

different bacteria that were isolated from the pond, tube-well and supply water were also resistant to some common commercially available antibiotics [83] [84] [85]. 
This multi-drug resistance might have arisen due to misuse of antibiotics or prolonged use of single antibiotic, horizontal gene transfer from pathogenic to common nonpathogenic bacteria present in water bodies, insufficient or lack of accurate management of hospital and medical wastes etc. The result suggested that immediate precautions should be taken by the government to stop the selling of antibiotics without prescription, should be increase the public awareness and will be ensure the proper use of antibiotics with perfect dosages by doctors and patient, respectively.

\subsection{Prevalence of Waterborne Diseases at the Study Area}

Water contamination is one of the main causes of health problems in human being. About 2.3 billion people are suffering from water related diseases worldwide [86] and more than 2.2 million people die in developing countries every year due to waterborne diseases [87]. Waterborne disease is the major burden in the study area. Most of these water borne diseases are attributed to the contaminated water that contains various infectious pathogens. Further, few people have been found in the study area who use proper water purification systems are free from these waterborne diseases. To investigate the impact of contaminated water on public health, 10 persons were taken from each sampling site during the study period of samples collection and total respondents were 300 (50\% were male and $50 \%$ female). Among the respondents, most of the people were aware about the reasons and treatment of scabies (65\%), skin diseases (69\%) and diarrhea (54\%), and very few were conscious about campylo-bacteriosis (1\%), salmonellosis (2\%), botulism (7\%) and hepatitis (23\%) (Table 2). Here, it was noticed that few people were suffering from those diseases from long time.

Table 2. Impact of waterborne diseases on public health.

\begin{tabular}{|c|c|c|c|c|c|c|c|}
\hline Diseases & $\begin{array}{l}\text { Clear concept about } \\
\text { reason and treatment }\end{array}$ & $\begin{array}{l}\text { Suffering from } \\
\text { a long time }\end{array}$ & Frequently & $\begin{array}{l}\text { Affected within } \\
\text { last year }\end{array}$ & $\begin{array}{l}\text { Affected within } \\
\text { last month }\end{array}$ & $\begin{array}{l}\text { Affected within } \\
\text { last week }\end{array}$ & $\begin{array}{c}\text { Took } \\
\text { antibiotic }\end{array}$ \\
\hline Diarrhea & 170 & 7 & 12 & 35 & 6 & 8 & 28 \\
\hline Dysentery & 140 & 3 & 8 & 5 & 16 & 5 & 23 \\
\hline Cholera & 95 & - & - & 9 & 8 & - & 15 \\
\hline Typhoid & 112 & - & - & 8 & 2 & 4 & 14 \\
\hline Hepatitis & 68 & - & - & 5 & 3 & 1 & 6 \\
\hline Botulism & 22 & - & 13 & 11 & 8 & 2 & 25 \\
\hline Campylo-bacteriosis & 2 & - & - & - & - & - & - \\
\hline Salmonellosis & 7 & - & - & 5 & - & - & 5 \\
\hline Scabies & 198 & 14 & 7 & 32 & 4 & 9 & 2 \\
\hline Skin diseases & 205 & 19 & 26 & 3 & 8 & 2 & 4 \\
\hline Skin cancer & 78 & - & - & - & - & - & - \\
\hline Dad & 134 & 5 & - & 2 & 3 & - & - \\
\hline Itching and rash on the skin & 163 & 22 & 18 & 9 & 3 & 7 & 5 \\
\hline
\end{tabular}


Highest rate for long time suffering of diseases was found for itching and rash on the skin (7\%). From 13 common diseases, most frequently occur disease was diarrhea. More than $11 \%$ people were found to be affected last year by diarrhea and scabies (10\%) and 5\% people were affected last month by dysentery. 3\% people were affected by scabies within last week. Among the diseases, highest number of antibiotic was taken for diarrhea (9\%), botulism (8\%) and dysentery (7\%). From this study a clear scenario that the dose of antibiotics were not completed by most of the respondents and the efficiency of these antibiotics were not satisfactory that also indicates the occurrence of antibiotic resistance. Government authorities should establish protocols to monitor the occurrence of water borne diseases and develop awareness programs to inform the communities about the symptoms, treatment and pattern of taking antibiotics.

\section{Conclusion}

Water is vital for the daily activities of life for drinking and different household works which is continuously polluted by municipal wastes and contaminated with different pathogenic bacteria. The quality of this water may impact on the incidence of various water-borne infectious diseases of human and threat for aquatic biota. The present study revealed that the physiochemical and bacterial quality of the water samples was out of the standard limit of WHO and risky for drinking, aquatic lives, domestic purposes due to the presence of pathogenic bacteria. The antibiotic resistant bacteria in these water resources pose a serious public health threat and responsible genes for antibiotic resistance are transferring from pathogenic to non-pathogenic organisms. It can be recommended that the government authorities should establish protocols to monitor water quality and develop awareness programs to inform the communities about the status of the water quality to reduce the burden from water-borne infection diseases.

\section{Conflicts of Interest}

The authors declare no conflicts of interest regarding the publication of this paper.

\section{References}

[1] Dianou, D., Savadogo, B., Zongo, D., Zougouri, T., Poda, J.N., Bado, H. and Rosillon, F. (2011) Surface Waters Quality of the Sourou Valley: The Case of Mouhoun, Sourou, Debe and Gana Rivers in Burkina Faso. International Journal of Biological and Chemical Sciences, 5, 1571-1589. https://doi.org/10.4314/ijbcs.v5i4.22

[2] Bhuiyan, M.A.H., Rakib, M.A., Dampare, S.B., Ganyaglo, S. and Suzuki, S. (2011) Surface Water Quality Assessment in the Central Part of Bangladesh Using Multivariate Analysis of the Country. KSCE Journal of Civil Engineering, 15, 995-1003. https://doi.org/10.1007/s12205-011-1079-y

[3] Buchholz, R.A. (1998) Principles of Environmental Management. The Greening of Business. 2nd Edition, Prentice-Hall, London.

[4] Alam, M.J.B., Islam, M.R., Muyen, Z., Mamun, M. and Islam, S. (2007) Water Qual- 
ity Parameters along Rivers. International Journal of Environmental Science \& Technology, 4, 159-167. https://doi.org/10.1007/BF03325974

[5] Higgins, I.J. and Burns, R.G. (1975) The Chemistry and Microbiology of Pollution. Academic Press, London, 256.

[6] Chitmanat, C. and Traichaiyaporn, S. (2010) Spatial and Temporal Variations of Physical-Chemical Water Quality and Some Heavy Metals in Water, Sediments and Fish of the Mae Kuang River, Northern Thailand. International Journal of Agriculture and Biology, 12, 816-820.

[7] Alkins-Koo, M, Lucas, F., Maharaj, L., Maharaj, S., Phillip, D., Rostant, W. and Surujdeo-Maharaj, S. (2008) Physicochemical Assessment of Surface and Groundwater Quality of the Greater Chittagong Region of Bangladesh. Ecological Indicators, 8, 709 .

[8] De, A.K. (2007) Environmental Chemistry. 6th Edition, New Age Int. (P) Ltd., Ram Nagar, New Delhi, 65+169-170.

[9] Dara, S.S. (2007) Environmental Chemistry and Pollution Control. 7th Edition, S. Chand and Company Ltd., New Delhi, 110-113.

[10] Khalil, M.K.H., Radwan, A.M. and El-Moselhy, K.H.M. (2007) Distribution of Phosphorus Fractions and Some of Heavy Metals in Surface Sediments of Burullus Lagoon and Adjacent Mediterranean Sea. Egyptian Journal of Aquatic Research, 33, 277-289.

[11] Shakweer, L.M. and Abbas, M.M. (2005) Effect of Ecological and Biological Factors on the Uptake and Concentration of Trace Elements by Aquatic Organisms at Edku Lake. Egyptian Journal of Aquatic Research, 31, 271-288.

[12] Abou El-Naga, E.H., El-Moselhy, K.H.M. and Hamed, M.A. (2005) Toxicity of Cadmium and Copper and Their Effect on Some Biochemical Parameters of Marine Fish Mugil Seheli. Egyptian Journal of Aquatic Research, 31, 60-71.

[13] Akturk, S., Dincer, S. and Toroglu, S. (2012) Determination of Microbial Quality and Plasmid-Mediated Multidrug Resistant Bacteria in Fountain Drinking Water Sources in Turkey. Journal of Environmental Biology, 33, 1127-1136.

[14] Khan, M.R., Saha, M.L. and Kibria, A.H.M.G. (1992) A Bacteriological Profile of Bottled Water Sold in Bangladesh. World Journal of Microbiology and Biotechnology, 8, 544-545. https://doi.org/10.1007/BF01201960

[15] Parveen, S., Ahmed, M.S.U. and Tania, N. (2008) Microbial Contamination of Water in Around Dhaka City. Bangladesh Journal of Scientific and Industrial Research, 43, 273-276. https://doi.org/10.3329/bjsir.v43i2.972

[16] Begum, F., Shahana, P., Begum, H.A. and Hoq, S. (1999) Microbiological Quality of Different Companies' Mineral and Drinking Water Available in Dhaka City. Bangladesh Journal of Scientific and Industrial Research, 1, 209-212.

[17] Mitra (1992) The 1991 National Survey on Status of Rural Water Supply and Sanitation for DPHE/UNICEF, Dhaka. Final Report, Bangladesh.

[18] Talukdar, P.K., Rahman, M., Rahman, M., Nabi, A., Islam, Z., et al. (2013) Antimicrobial Resistance, Virulence Factors and Genetic Diversity of Escherichia coli Isolates from Household Water Supply in Dhaka, Bangladesh. PLOS ONE, 8, e61090. https://doi.org/10.1371/journal.pone.0061090

[19] Svara, F. and Rankin, D.J. (2011) The Evolution of Plasmid-Carried Antibiotic Resistance. BMC Evolutionary Biology, 11, Article No. 130. https://doi.org/10.1186/1471-2148-11-130

[20] WHO (World Health Organization) (2008) Guidelines for Drinking-Water Quality. 
3rd Edition, WHO: Geneva, Switzerland.

[21] Fenwick, A. (2006) Waterborne Diseases-Could They Be Consigned to History? Science, 313, 1077-1081. https://doi.org/10.1126/science.1127184

[22] Grabow, W.O.K. (1996) Waterborne Diseases: Update on Water Quality Assessment and Control. Water $S A, 22,193-202$.

[23] Balan, I., Shivakumar, M. and Kumar, P.M. (2012) An Assessment of Groundwater Quality using Water Quality Index in Chennai, Tamil Nadu, India. Chronicles of Young Scientists, 3, 146-150. https://doi.org/10.4103/2229-5186.98688

[24] Prescott, L.M., Harley, J.P. and Klein, D.A. (2002) Microbiology: Food and Industrial Microbiology. 5th Edition, McGraw-Hill, Boston, 978-981.

[25] Auer, M.T. and Niehaus, S.L. (1993) Modeling Fecal Coliform Bacteria-I. Field and Laboratory Determination of Loss Kinetics. Water Research, 27, 693-701. https://doi.org/10.1016/0043-1354(93)90179-L

[26] Kabir, S.L., et al. (2015) Safety Assessment of Tubewell Water at Fulbaria pourasava in Mymensingh District of Bangladesh. International Journal of Natural and Social Sciences, 2, 89-94.

[27] International Commission on Microbiological Specifications for Foods (ICMSF) (1985) Microorganism in Foods; Samples for Microbiological Analysis: Principles and Specific Applications, Recommendation of the International Commission on Microbiological Specification for Foods. Association of Microbiological Societies, University of Toronto Press, Toronto.

[28] Krieg, N.R., Holt, J.G., Sneath, P.H.A., Staley, J.T. and Williams, S.T. (1994) Bergey's Manual of Determinative Bacteriology. 9th Edition, Williams \& Wilkins, Baltimore, MD.

[29] Sneath, P.H., Mair, N.S., Sharpe, M.E. and Holt, J.G. (1986) Bergey's Manual of Systematic Bacteriology. Williams \& Wilkins, Baltimore, MD.

[30] Al-Salauddin, A.S., et al. (2015) Isolation, Identification, and Antibiogram Studies of Salmonella Species and Escherichia coli from Boiler Meat in Some Selected Areas of Bangladesh. International Journal of Basic \& Clinical Pharmacology, 4, 999-1003. https://doi.org/10.18203/2319-2003.ijbcp20150881

[31] Reza, A. and Yousuf, T.B. (2016) Impacts of Waste Dumping on Water Quality in the Buriganga River, Bangladesh and Possible Mitigation Measures. Journal of the Environment, 11, 35-40.

[32] Roche, L.M., Kromschroeder, L., Atwill, E.R., Dahlgren, R.A. and Tate, K.W. (2013) Water Quality Conditions Associated with Cattle Grazing and Recreation on National Forest Lands. PLoS ONE, 8, e68127.

https://doi.org/10.1371/journal.pone.0068127

[33] Lira, S.A., Akter, F., Rahman, T. Islam, S., Tanvir, R.Z., Al Salauddin, A.S., Farhad Hossain, M., Shaon, S.M. Rana, M. and Mahmud, S. (2016) Investigation of Coliform Load, Supplied Water Quality and Sanitation Status of Sherpur Municipality of Bangladesh. British Microbiology Research Journal, 12, 1-8.

[34] World Health Organization (2004) Guidelines for Drinking-Water Quality. Vol. 1, World Health Organization.

[35] Volk, C., et al. (2002) Monitoring Dissolved Organic Carbon in Surface and Drinking Waters. Journal of Environmental Monitoring, 4, 43-47. https://doi.org/10.1039/b107768f

[36] Ahipathi, M.V. and Puttaiah, E.T. (2006) Ecological Characteristics of Vrishabhavathi River in Bangalore (India). Environmental Geology, 49, 1217-1222. 
https://doi.org/10.1007/s00254-005-0166-0

[37] Tania Sultana, A.S.M., Saifullah, M.M., Roy, S. and Al Mamun, S.(2012) Assessment of Surface Water Quality: A Case Study of Tangail Municipal Area, Bangladesh. Bangladesh Journal of Scientific Research, 25, 155-163.

[38] ECR (1997) The Environment Conservation Rules. Government of the People's Republic of Bangladesh. Ministry of Environment and Forest. 205-207.

[39] Shrivastava, N., Mishra, D.D., Mishra, P.K. and Bajpai, A. (2013) Water Quality Deterioration of Machna River due to Sewage Disposal, Betul, Madhya Pradesh, India. Journal of Environment and Earth Science, 3, 15.

[40] Raja, P.A. (2008) Evolution of Physical and Chemical Parameters of River Kaveri, Trichy. Indian Journal of Environmental Biology, 29, 756-768.

[41] WHO (World Health Organization) (2010) Water for Health: Guidelines for Drinking Water Quality. WHO, Geneva, 1-6.

[42] Islam, M.S., Siddika, A., Khan, M.N.H., Goldar, M.M., Sadique, M.A., Kabir, A.N.M.H., Huq, A. and Colwell, R.R. (2001) Microbiological Analysis of Tube-Well Water in a Rural Area of Bangladesh. Applied and Environmental Microbiology, 67, 3328-3330. https://doi.org/10.1128/AEM.67.7.3328-3330.2001

[43] Meade, J.W. (2012) Aquaculture Management. Springer Science \& Business dia, Berlin, , Heidelberg.

[44] Kawasaki, J. (2002) Animal Science and Livestock Production. Library and Information Science, 135-156.

[45] Environmental Quality Standard for Bangladesh (1993) Department of Environment (DoE), Ministry of Environment and Forest, Government Republic of Bangladesh.

[46] Islam, M.J., Akter, A., Kamrujjaman, M., Siddiqa, A. and Aktar, S. (2013) Assessment of Pond Water Quality of Thakurgaon Sadar Upazila for Fish Production. International Journal of Agricultural Research, Innovation and Technology, 3, 29-34. https://doi.org/10.3329/ijarit.v3i1.16052

[47] Hu, K., Huang, Y., Li, H., Li, B., Chen, D. and White, R.E. (2005) Spatial Variability of Shallow Groundwater Level, Electrical Conductivity and Nitrate Concentration and Risk Assessment of Nitrate Contamination in North China Plain. Environment International, 31, 896-903. https://doi.org/10.1016/j.envint.2005.05.028

[48] Gupta, P.K. (2001) Methods in Environmental Analysis: Water, Soil and Air. Agro-Bios, Hassan, India, 12-17.

[49] Alam, M.F., Dafader, N.C., Sultana, S., Rahman, N. and Taheri, T. (2017) Physico-Chemical Analysis of the Bottled Drinking Water Available in the Dhaka City of Bangladesh. Journal of Materials and Environmental Science, 8, 2076-2083.

[50] Khan, M.A., Hossain, A.M., Huda, M.E., Islam, M.S. and Elahi, S.F. (2007) Physico-Chemical and Biological Aspects of Monsoon Waters of Ashulia for Economic and Aesthetic Applications: Preliminary Studies. Bangladesh Journal of Scientific and Industrial Research, 42, 377-396. https://doi.org/10.3329/bjsir.v42i4.747

[51] Rahman, A., Ahamed, P., Jamal, M., Salam, M.A. and Yousuf, M.A. (2017) Analyses of Private Drinking Tube-Wells Water from Kushtia District, Bangladesh. Journal of Engineering, 8, 87-94.

[52] Saha, M.L., Nessa, M., Khan, M.R., Islam, M.N. and Hoque, S. (2012) Bacteriological and Physicochemical Water Quality of Four Ponds of Dhaka Metropolis. Bangladesh Journal of Botany, 41, 55-60. https://doi.org/10.3329/bjb.v41i1.11083

[53] Champa, H. and Kabir, S.L. (2018) Microbial Analysis of Tap Water Collected from 
Selected Upazillas of Jamalpur, Tangail, Kishoreganj and Netrokona Districts of Bangladesh. Asian Journal of Medical and Biological Research, 4, 193-200. https://doi.org/10.3329/ajmbr.v4i2.38255

[54] Water Security Agency (2017) Microbiological Quality: Understanding Drinking Water Quality and Management, EPB 197.

[55] Miah, M.B., Majumder, A.K. and Latifa, G.A. (2016) Evaluation of Microbial Quality of the Surface Water of Hatirjheel in Dhaka City. Stamford Journal of Microbiology, 6, 30-33. https://doi.org/10.3329/sjm.v6i1.33516

[56] Rahman, M.A., Sultana, S. and Salam, M.A. (2015) Comparative Analysis of some Water Quality Parameters of three Lakes in Jahangirnagar University Campus, Savar, Bangladesh. Bangladesh Journal of Zoology, 43, 239-250. https://doi.org/10.3329/bjz.v43i2.27395

[57] Haque, M.A., Jewel, M.A. and Sultana, M.P. (2019) Assessment of Physicochemical and Bacteriological Parameters in Surface Water of Padma River, Bangladesh. Applied Water Science, 9, 10. https://doi.org/10.1007/s13201-018-0885-5

[58] Afrin Nitol, S., Mahbub Kabir, M., Sultana, F., Sultana, N., Hossain, S. and Saadat, A.H.M. (2016) Quality Analysis of Potable Water at Dakshin Khan in Dhaka City. Bangladesh Journal of Biodiversity and Environmental Sciences, 8, 128-135.

[59] Rahman, M.A., Islam, M.M. and Ahmed, F. (2015) Physico-Chemical and Bacteriological Analysis of Drinking Tube-Well Water from Some Primary School, Magura, Bangladesh to Evaluate Suitability for Students. International Journal of Applied Science and Engineering Research, 4, 735-749.

[60] Dufour, A. (1984) Health Effects Criteria for Fresh Recreational Waters. EPA Document Number EPA-600.

[61] Mihir Lal, S., Nessa, M., Mahbubar Rahman, K., Islam Mohammad N. and Sirajul, H. (2012) Bacteriological and Physicochemical Water Quality of Four Ponds of Dhaka Metropolis. Bangladesh Journal of Botany, 41, 55-60. https://doi.org/10.3329/bjb.v41i1.11083

[62] Parvez, A.K., Liza, S.M., Marzan, M., Ahmed, A. and Hahedur Rahman, M. (2016) Bacteriological Quality of Drinking Water Samples across Bangladesh. Archives of Clinical Microbiology, 7, 1-6.

[63] Godfree, A., Kay, D. and Wyer, M. (1997) Fecal Streptococci as Indicators of FecalContamination in Water. Journal of Applied Microbiology, 83, 110-119. https://doi.org/10.1046/j.1365-2672.83.s1.12.x

[64] Johnson, T.J., Siek, K.E., Johnson, S.J. and Nolan, L.K. (2006) DNA Sequence of a ColV Plasmid and Prevalence of Selected Plasmid Encoded Virulence Genes among Avian Escherichia coli Strains. Journal of Bacteriology, 188, 745-758. https://doi.org/10.1128/JB.188.2.745-758.2006

[65] Pruss, A. (1998) Review of Epidemiological Studies on Health Effects from Exposure to Recreational Water. International Journal of Epidemiology, 27, 1-9. https://doi.org/10.1093/ije/27.1.1

[66] Sahana Parveen, M., Uddin Ahmed, S. and Nasreen, T. (2008) Microbial Contamination of Water in Around Dhaka City. Bangladesh Journal of Scientific and Industrial Research, 43, 273-276. https://doi.org/10.3329/bjsir.v43i2.972

[67] Mahmud, T., Kumar Mukharjee, S., Khalil, I., Rahman, A. and Hossen, F. (2016) Physicochemical and Microbiological Analysis of Tube-Well Water from Noakhali District, Bangladesh. World Journal of Microbiology, 3, 50-055.

[68] Gurumayum, S., Senapati, S.S., Rasane, P. and Kaur, S. (2018) Shigella: A Threat to 
the Food Industry. In: Food Safety, Apple Academic Press, Palm Bay, FL, 197-220.

[69] Germani, Y. and Sansonetti, P.J. (2003) The Genus Shigella. In: Dworkin, M., Falkow, S. and Rosenberg, E., Eds., The Prokaryotes: An Evolving Electronic Resource for the Microbiological Community, 3th Edition, Springer-Verlag, New York.

[70] Alamanos, Y., Maipa, V., Levidiotou, S. and Gessouli, E. (2000) A Community Waterborne Outbreak of Gastro-Enteritis Attributed to Shigella sonnei. Epidemiology \& Infection, 125, 499-503. https://doi.org/10.1017/S0950268800004866

[71] Bennish, M.L. (1991) Potentially Lethal Complications of Shigellosis. Reviews of Infectious Diseases, 13, S319-S324. https://doi.org/10.1093/clinids/13.Supplement_4.S319

[72] Le Minor (2003) The Genus Salmonella. In: Dworkin, M., Falkow, S. and Rosenberg, E., Eds., The Prokaryotes: An Evolving Electronic Resource for the Microbiological Community, 3th Edition, Springer-Verlag, New York.

[73] Escartin, E.F., et al. (2002) Potential Salmonella Transmission from Ornamental Fountains. Journal of Environmental Health, 65, 9-12.

[74] Prosun, T.A., Rahaman, S., Rikta, S.Y. and Rahman, A. (2018) Drinking Water Quality Assessment from Ground Water Sources in Noakhali, Bangladesh. International Journal of Development and Sustainability, 7, 1676-1687.

[75] Acharjee, M., Rahman, F., Beauty, S.A., Feroz, F., Rahman, M.M. and Noor, R. (2011) Microbiological Study on Supply Water and Treated Water in Dhaka City. Stamford Journal of Microbiology, 1, 42-45. https://doi.org/10.3329/sjm.v1i1.9132

[76] Baker-Austin, C., Oliver, J.D., Alam, M., Ali, A., Waldor, M.K., Qadri, F. and Martinez-Urtaza, J. (2018) Vibrio Spp. Infections. Nature Reviews Disease Primers, 4, Article No. 8. https://doi.org/10.1038/s41572-018-0005-8

[77] Islam, M.S., Drasar, B.S. and Sack, R.B. (1993) The Aquatic Environment as a Reservoir of Vibrio cholerae: A Review. Journal of Diarrhoeal Diseases Research, 11, 197-206.

[78] Farmer, J.J. and Hickam-Brenner, F.W. (2003) The Genus Vibrio and Phtotobacterium. In: Dworkin, M., Falkow, S. and Rosenberg, E., Eds., The Prokaryotes: An Evolving Electronic Resource for the Microbiological Community, 3th Edition, Springer-Verlag, New-York.

[79] Farmer, J.J., Janda, J.M., Brenner, F.W., Cameron, D.N. and Birkhead, K.M. (2005) Genus Vibrio. In: Brenner, D.J., Krieg, N.R. and Staley, J.T., Eds., Bergey's Manual of Systematic Bacteriology, 2nd Edition, Springer, New York, 494-546.

[80] Mahbub, K.R., Paul, K.P. and Ahmed, M.M. (2011) Prevalence of Vibrio Spp and Antibiogram of Isolates from Shrimp Rearing Ponds in Bangladesh. Journal of Advanced Scientific Research, 2, 74-80.

[81] George, C.M., Hasan, K., Monira, S., Rahman, Z., Saif-Ur-Rahman, K.M., Rashid, M.U., Zohura, F., Parvin, T., Bhuyian, M.S., Mahmud, M.T. and Li, S. (2018) A Prospective Cohort Study Comparing Household Contact and Water Vibrio cholerae Isolates in Households of Cholera Patients in Rural Bangladesh. PLoS Neglected Tropical Diseases, 12, e0006641. https://doi.org/10.1371/journal.pntd.0006641

[82] Mahmud, M.T., Mukharjee, S.K., Khalil, M.I., Rahman, M.A. and Hossen, F. (2016) Physicochemical and Microbiological Analysis of Tube-Well Water from Noakhali District, Bangladesh. World, 3, 50-55.

[83] Neela, F.A., Banu, M.N., Rahman, M.A., Rahman, M.H. and Alam, M.F. (2015) Occurrence of Antibiotic Resistant Bacteria in Pond Water Associated with Integrated Poultry-Fish Farming in Bangladesh. Sains Malaysiana, 44, 371-377. 
https://doi.org/10.17576/jsm-2015-4403-08

[84] Datta, R.R., Hossain, M.S., Aktaruzzaman, M. and Fakhruddin, A.N. (2014) Antimicrobial Resistance of Pathogenic Bacteria Isolated from Tube Well Water of Costal Area of Sitakunda, Chittagong, Bangladesh. Open Journal of Water Pollution and Treatment, 1, 1-6.

[85] Mahbub, K.R., Nahar, A., Ahmed, M.M. and Chakraborty, A. (2011) Quality Analysis of Dhaka WASA Drinking Water: Detection and. Journal of Environmental Science and Natural Resources, 4, 41-49. https://doi.org/10.3329/jesnr.v4i2.10133

[86] UNESCO (2003) Water for People Water for Life. The United Nations World Water Development Report. United Nations Educational, Scientific and Cultural Organization (UNESCO) and Berghahn Books.

[87] WHO and UNISEF (2000) Global Water Supply and Sanitation Assessment 2000 Report. World Health Organization and United Nations Children's Fund. 